\title{
In Memoriam Walter (Walt) Goodrich Jennings
}

\author{
Edward R. Adlard
}

Published online: 11 August 2012

(C) Springer-Verlag 2012

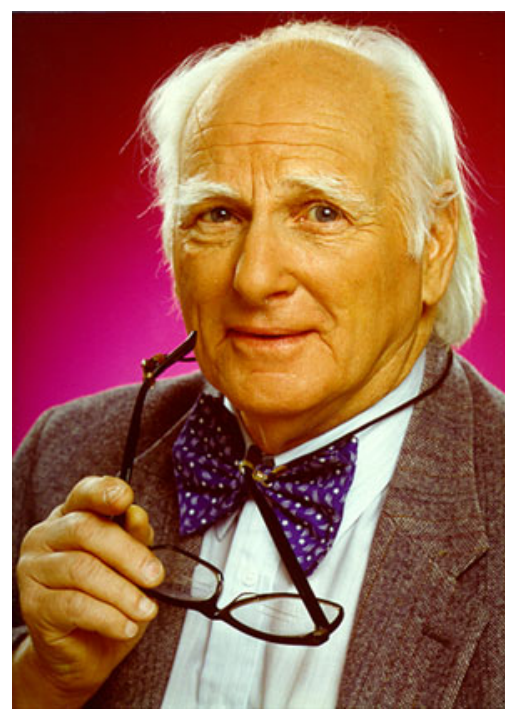

It is with great sadness that I report the death of Walt Jennings on July 5th aged 90 years, peacefully at home in the presence of his family.

Walt was born in Iowa but grew up in Glendale California, before it effectively became a satellite of Los Angeles. In his late teens he took part in a survey team exploring a route for the Union Pacific Railroad often travelling by mule across the rugged terrain of southern Nevada, California and Arizona. On the outbreak of war Walt joined the Army and served with distinction in Europe where he met his wife Erika. At the end of hostilities he took up a grant to US ex-servicemen to obtain a qualification and decided to obtain a degree in dairy science

E. R. Adlard ( $\bowtie)$

Burton, South Wirral, UK

e-mail: chromatographia@springer.com from the University of California at Davis to enter a family dairy business. However, rather than entering business this turned into a 38-year-long academic career from undergraduate to Professor Emeritus. Walt developed an interest in food and flavour chemistry and quickly realised the power of the new technique of gas chromatography. He built a GC in 1955 which must have made him one of the earliest workers in this field in the USA, outside the petroleum industry. Discovery and innovation in gas chromatography became a life-long passion resulting in many innovations, the most important of which was the development of cross-linked phases for capillary columns which could be tuned to specific separations.

Walt was a productive researcher with over 200 publications including eight books and several book chapters. His book Analytical Gas Chromatography, published by Academic Press in 1997 is still relevant today. He was highly sought after as a speaker, travelling world-wide in the process often delivering more than thirty presentations a year. At an Honorary Colloquium at the University of California, Davis in 2009 Walt made an estimate that he had lectured to more than 30,000 chromatographers from all walks of life - a truly remarkable achievement. In his career, Walt was recognized with many awards for his contributions in gas chromatography. Notable among these were The Humboldt Fellowship from the Alexander von Humboldt Foundation in 1973, The Founders Award in Gas Chromatography from the Beckman Foundation, The M.J.E. Golay Award from the International Symposium on Capillary Chromatography in 1996, the Keene P. Dimick Award from the Pittsburgh Conference in 1997 and the A.J.P. Martin Gold Medal from the Chromatographic Society in 1997.

I first met Walt in the early 1970s at the Shell agrochemical research lab in Kent. I happened to be visiting 
this lab and my host told me that they had an American visitor giving a one-day course on GC. Intrigued (and rather piqued since I was regarded as the company expert on the subject in the UK), I attended the talks and after one or two probing questions on either side we both recognised each other's worth and formed a close friendship that lasted for the rest of our lives. However, the occasion that sticks in my mind most vividly was at the 13th ISC at Cannes in 1980. I had been given some of the new silica capillary columns to try by Hewlett Packard and at one of the sessions I got up and expressed the opinion that glass columns were finished. This remark was greeted with hostility by some of the academics present until Walt got up and said that he totally agreed with me, and that he had four glass drawing machines that he was willing to sell cheaply to any interested party. This effectively silenced the opposition and the rest is history! Like many of the notable figures, it has been my privilege to have met over the years, it would have been easy to fill several pages with anecdotes about Walt, but I have perforce to confine myself to the most important aspects of his career. I am indebted to Dr. Phil Stremple of Agilent for information about Walt's work.

Walt was small man with a large personality. Few could hold an audience for the time that Walt did almost routinely for more than 30 years, always with something novel and interesting to say, usually enlivened with his sharp wit. We should give thanks to a life devoted to the service of humanity and offer our deep condolence to his family, his son Jeff and daughters, Sue and Peggy. 